\title{
Detection of Coxiella burnetii Infection in Various Organs from Beef Cattle in Depok, West Java, Indonesia
}

\author{
Elok Puspita Rini \\ Faculty of Veterinary Medicine \\ IPB University \\ Bogor, Indonesia \\ elokpuspitarini@gmail.com \\ I Wayan Teguh Wibawan \\ Faculty of Veterinary Medicine \\ $I P B$ University \\ Bogor, Indonesia \\ teguhwibawan@yahoo.co.id
}

\author{
Agus Setiyono \\ Faculty of Veterinary Medicine \\ IPB University \\ Bogor, Indonesia \\ agusse@apps.ipb.ac.id \\ Vetnizah Juniantito \\ Faculty of Veterinary Medicine \\ IPB University \\ Bogor, Indonesia \\ juniantito@gmail.com
}

\author{
Dwi Astuti \\ Division of Zoology \\ Indonesian Institute of Sciences (LIPI) \\ Bogor, Indonesia \\ asdwi2016@gmail.com
}

\begin{abstract}
Coxiella burnetii (C. burnetii) is negative Gram bacteria that caused zoonotic disease $Q$ fever. The main reservoir of this disease are ruminants such as cow, goat, and sheep. $Q$ fever infection happened to human relatively easily through aerosol, direct contact, and consumption of animal products from infected animal that has not been appropriately handled. This disease spread to almost all corner of the world and is a threat to food security and bioterrorism. Identification of $C$. burnetii infection in beef cattle in Indonesia is still limited. This research aim was to detect $C$. burnetii infection in various organs of beef cattle from Depok, Indonesia, through molecular examination using nested PCR (nPCR). The result of this research showed that the samples are identified to be positive of $Q$ fever through nPCR method in various organs. Distribution of infection detected on heart, spleen, and kidney that mostly found in spleen and heart. This result indicates that $C$. burnetii probably can caused endocarditis in beef cattle like in human. This result also give a warning to more attention to the zoonotic threats for human in slaughter house.
\end{abstract}

Keywords-Qfever, Depok, nested PCR

\section{INTRODUCTION}

Query fever or $Q$ fever is a disease caused by Coxiella burnetii (C. burnetii), which also called coxiellosis. Q fever causative agent was first isolated by Macfarlane Burnet and Mavis Freeman in 1937. At that time, Q fever agent was assumed to come originate from rickettsia [1, 2]. Cox and Gordon Davis in 1938 were able to isolate Q fever causative agent from ticks in Montana, USA. This agent has similarity with proteobacterium group, which are Legionella and Francisella. This agent was then named Coxiella burnetii which is included to Proteobacterium, Class Gammaproteobacteria, ordo Legionellales, and family Coxiellaceae $[1,3]$.

$Q$ fever is included as zoonotic disease that can be transmitted from animal to human and vice versa. Livestock such as cow, goat, and sheep are the main reservoir of this disease. Wildlife and pet animal, especially mammals, can be a source of infection. Presence of ectoparasite such as tick can also serve as potential vector for the spread of the disease. The main route of infection from this disease is through inhalation but can also happen per oral. Direct contact or inhalation of secreta, excreta, and remains of aborted fetus from infected animal can be a source of infection to both animal and human. Milk and meat consumption originating from infected animal that are not properly handled can be another source of infection. This becomes a threat to animal derived food safety $[1,2,4,5]$.

$\mathrm{Q}$ fever is a zoonotic disease that has spread in various countries. Based on OIE data in 2017, Q fever distribution happens in all countries in the world. Canada, USA, Australia, and several countries in Europe, Africa, and ASEAN have reported the presence of $Q$ fever infection in animal [6]. $Q$ fever has been an important health problem in various countries such as United States, France, Britain, Italy, Germany, Spain, Canada, Japan, Australia, South Korea, Taiwan, and several other countries in South East Asian. United States of America categorized Q fever as category B bioterrorism agent as this agent is moderately easy to spread [7].

Indonesia has not yet to provide information on Q fever cases reported officially. This is because the clinical symptom of this disease is asymptomatic and thus often mistaken by other disease and ended up undiagnosed [8]. Q fever was first found in Indonesia on 1953. Kaplan and Bertagna in 1955 reported 188 cow serum were positive of $\mathrm{Q}$ fever [9]. Identification and study on $\mathrm{Q}$ fever disease after 1953 in Indonesia has never been reported again. New researches began again from 2006 to 2015 [8, 10]. This research has the aim to detection of $C$. burnetii infection in various organs of beef cattle from Depok, Indonesia, through molecular examination using nested nPCR. 


\section{MATERIALS AND METHODS}

\section{A. Sample}

Samples used in this research are heart, lung, liver, spleen, and kidney tissue from beef cattle that slaughtered in slaughterhouses in Depok region in 2017. Each organ were trimmed into $3 \mathrm{~cm}$ thick and it was coated by aluminium foil and piy inside cool box filled with ice pack and stored in $-30{ }^{0} \mathrm{C}$ freezer for molecular examination. Samples were taken by purposive random sampling with 50 samples of beef cattle.

\section{B. DNA extraction and amplification by $n P C R$}

Frozen fresh tissue of each organ were weighted to 3-5 $\mathrm{mg}$ each and grind for extraction. DNA extraction was performed by using DNA purification kit puregene/puregene DNA purification kit; solid tissue protocol (Qiagen $\left.{ }^{\circledR}\right)$. DNA extraction procedure used was according to the provided guide book. The examination were by pooling 10 cows per sample.

DNA amplification was performed by conventional PCR using two-step method or nPCR. Primer used in PCR test can be seen in Table 1. Sample DNA amplification was performed by using thermal cycler (Perkin-Elmer Gene Amp PCR systems 9600). First PCR was programme for 35 cycles. Denaturation process were done in $94{ }^{\circ} \mathrm{C}$ for 1 minute, annealing in $54{ }^{\circ} \mathrm{C}$ for 1 menit, and extention in 72 ${ }^{\circ} \mathrm{C}$ for 2 minutes. Expected PCR first product is DNA with 501 bp lenghth [11].

$2^{\text {nd }}$ round (nested $\mathrm{PCR}$ ) was also programmed to be done in 35 cycles. It begins with heating in $94^{\circ} \mathrm{C}$ for 3 minutes, followed by denaturation in $94^{\circ} \mathrm{C}$ for 1 minute, annealing in $56^{\circ} \mathrm{C}$ for 1 minute, extention in $72^{\circ} \mathrm{C}$ for 1 minute 30 second, and final extention in $72^{\circ} \mathrm{C}$ for 4 minutes, and finally cooling in $4^{\circ} \mathrm{C}$. Expected nested PCR product is $437 \mathrm{bp}$ length [11]. Primers that used in nPCR shown in Table 1 that previously described in [12].

The result of DNA amplification through PCR then read by gel electrophoresis. Electrophoresis reading were visualized as DNA fragments in bands. Visualisation of electrophoresis result were done by ultraviolet illuminator and captured by camera.

TABLE I PRIMERS USED IN NESTED PCR

\begin{tabular}{|c|c|c|}
\hline PCR Step & Primer & Base sequence \\
\hline \multirow{2}{*}{$1^{\text {st }}$ round } & OMP1 & $\begin{array}{l}5^{\circ} \text {-AGT AGA AGC ATC CCA } \\
\text { AGC ATT-3' }\end{array}$ \\
\hline & OMP2 & $\begin{array}{l}\text { 5'-TGC CTG CTA GCT GTA } \\
\text { ACG ATT-3' }\end{array}$ \\
\hline \multirow{2}{*}{$\begin{array}{c}2^{\text {nd }} \text { round } \\
(n \mathrm{PCR})\end{array}$} & OMP3 & $\begin{array}{l}5^{\prime}-\mathrm{GAA} \text { GCG CAA CAA GAA } \\
\text { GAA CAC-3' }\end{array}$ \\
\hline & OMP4 & 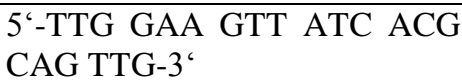 \\
\hline
\end{tabular}

\section{RESULTS}

There are three positive samples from nPCR examination. The positive result is found on heart, lung, kidney, and spleen that shown on Table 2 and the electrophoresis result from the positive samples shown in Fig. 1.

TABLE II. RESULT OF NPCR IN VARIOUS ORGAN

\begin{tabular}{|c|c|c|c|c|c|}
\hline \multirow{2}{*}{ Pooling } & \multicolumn{5}{|c|}{ Positive Organs } \\
\cline { 2 - 6 } & Heart & Lung & Liver & Kidney & Spleen \\
\hline 1 & - & - & - & - & - \\
\hline 2 & - & + & - & + & + \\
\hline 3 & - & - & - & - & + \\
\hline 4 & - & - & - & - & - \\
\hline 5 & + & - & - & + & - \\
\hline
\end{tabular}

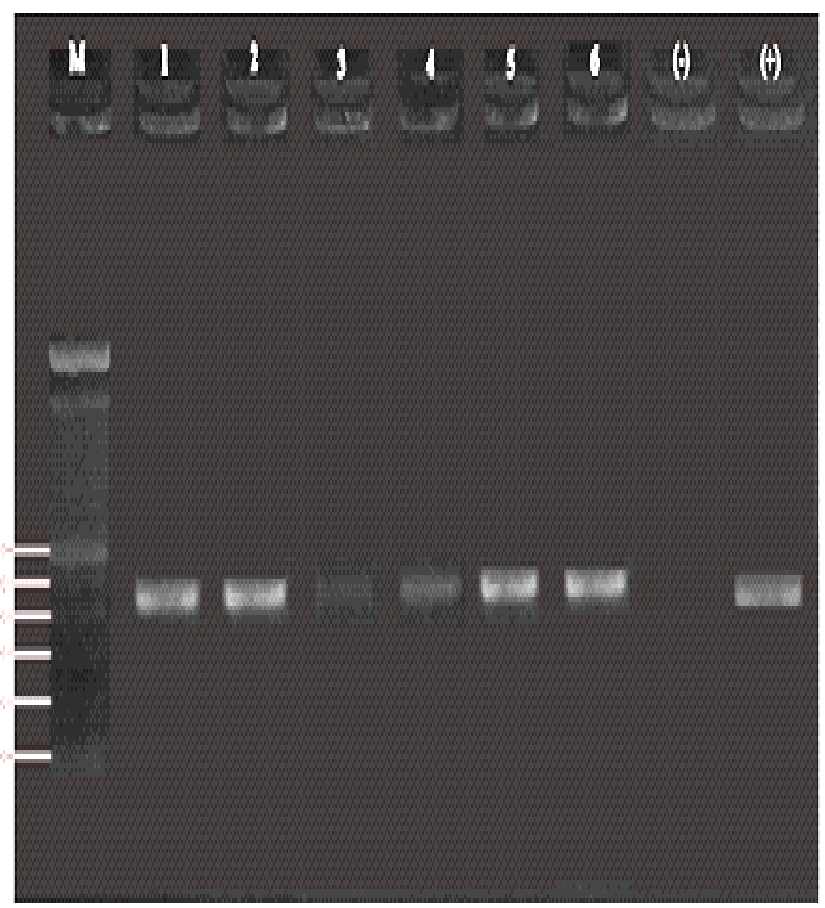

Fig. 1. Electrophoresis result of nPCR from various organs. M (marker); 1 (lung, pooling 2); 2 (kidney, pooling 2); 3 (spleen, pooling 2); 4 (spleen, pooling 3);5 (heart, pooling 5); 6(kidney, pooling 5); (-) (negative control); (+) (positive control)

The infection of $C$. burnetii apparently distributed to various organs. Kidney and spleen are the organs that most effecting of infection. Heart and lung also infected of $C$. burnetii, but in liver not detect of infection. Distribution of infection of $C$. burnetii shown in Fig. 2. 


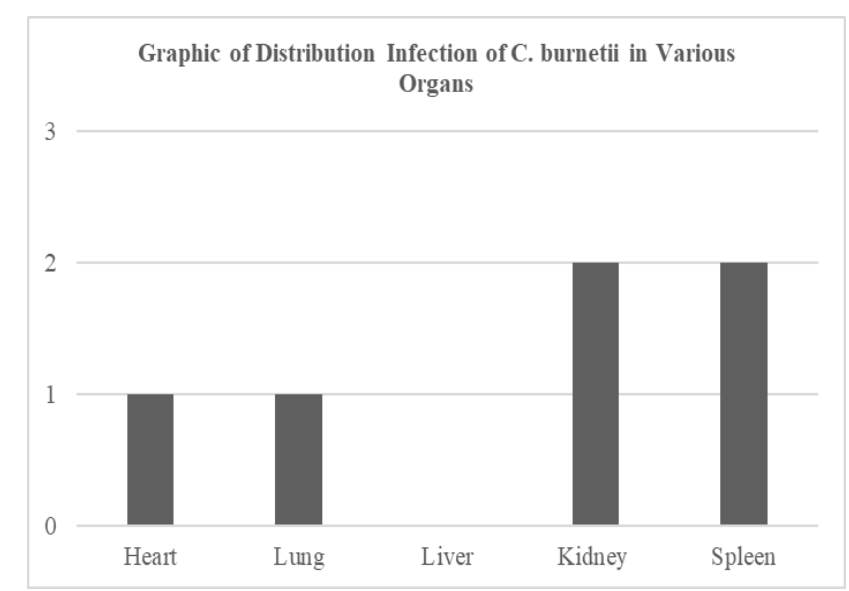

Fig2. Distribution Infection of $C$. burnetti in various organs

\section{DISCUSSION}

Coxiella burnetii infection widely spreads across the globe and causes health issues either to human and animals. Indonesia is considered by OIE as "no information" country group from 2016 to 2019. Nonetheless, Indonesia was ever on "infection/infestation" group on 2015 [13]. Identification and research of this disease has not been done a lot in Indonesia therefore the lack of official data is occurred. According to this study, beef cattle that slaughtered in slaughterhouse in Depok positively infected of $C$. burnetii by PCR examination (Table 2). This result gives addition information of data about which region in Indonesia that got positively infected by $Q$ fever. $Q$ fever identification on ruminants in Indonesia had been done before in Bogor, Bali, Medan, and several others region $[8,10]$. This result also can give a picture of that $\mathrm{Q}$ fever already spread over some regions in Indonesia. However, Q fever has not yet been known by people in Indonesia, thus quite often misunderstood as another illness with same symptoms [8]. Q fever in ruminants is linked with the incidence of abortus and reproduction disorder such as metritis. C. burnetii may survive in host for several years with subclinical symptoms. Animals suffering from subclinical Q fever may still excrete $C$. burnetii to the environment. Q fever can cause abortus in the last third trimester of gestation and pneumonia in cattle. Reproductive abnormalities and abortion can cause economical loss to the farmers.

Positive result of $\mathrm{Q}$ fever on cattle in slaughterhouse from this study give zoonosis and community health threat for slaughterhouse workers, veterinarian, animal keeper, and to the people who directly contact with that animals. Main infection route from animal to human is airborne. Route of infection to human by airborne has $50 \%$ infection rate by 1.18 bacteria (infD50\%) and $50 \%$ illness rate by 5.58 bacteria (IllD50\%) [15]. Flu-like syndrome, pneumonia, hepatitis, and nephritis are acutely signs of $\mathrm{Q}$ fever on human. This signs respond definitively differ to each individual from mild to severe. However, most of this acute signs are self-limiting yet can develop to chronic and cause endocarditis. It has high morbidity rate yet low mortality rate.

In Fig. 2 showed that infection widely spread through almost all over the body organs, that means infection systemically occurred. Infection most likely occurred on kidney and spleen. Infection is also found on heart and lung. Lung and kidney infection to be thought related to acute Q fever that distribute to circulation system therefore heart is infected as well. Spleen is the most important organ on lymphatic system so that systemic infection of $C$. burnetii cause infection to spleen too. More research is needed for advance diagnostic using immunohistochemistry and histopathological examination to determined infection pattern in various organs and to investigate the pathogenesis.

\section{ACKNOWLEDGMENT}

This writing is one part of projects that funded and sponsored by Ministry of Education and Culture (formerly known as Ministry of Research and Higher Education)

\section{REFERENCES}

[1] Honarmand H. 2012. Q fever: an old but still a poorly understood disease. hindawi publishing corporation, Interdisc Perspec on Infect Dis :1-8.

[2] Maurin M, Roult D. 1999. Q fever. Clin Microbiol Rev. 12(4): 518-553.

[3] Davis GE, Cox HR. 1938. A filter-passing infectious agent isolated from ticks $1^{\text {st }}$ solation from Dermacentor andersonii, reactions in animals, and filtration. Pub Health Rep. 53(52): 2259-2282.

[4] Porter SR, Czapilicki G, Mainil J, Guatteao R, Saegerman C. 2011. Q fever: current state of knowledge and perspective of research of a neglected zoonosis. Int. Journal of Microb.doi:10.1155/2011/248418.

[5] Hansen MS, Rodolakis A, Cochonneau D, Jens F. Agger JF, Christoffersen AB, Jensen TK, Agerholm JS. 2011. Coxiella burnetii associated placental lesions and infection level in parturient cows. Vet J. 190:135-139.

[6] [OIE] World Organization of Animal Health. 2017. Q fever worldwide situation. https://www.oie.int/wahis_2/public/wahid.php/Diseaseinformatio n/Diseasedistributionmap/index/newlang/en?disease_type_hidde $\mathrm{n}=\&$ disease_id_hidden $=\&$ selected_disease_name_hidden $=\&$ dise ase_type $=0 \&$ disease_id_terrestrial $=22 \&$ species_t $=0 \&$ disease_id _aquatic=-

999\&species_a=0\&sta_method=semesterly\&selected_start_year $=2017 \&$ selected_report_period $=1 \&$ selected_start_month $=1 \&$ dat e_submit=OK

[7] Angelakis E, Raoult D. 2011. Emergence of q fever. Iranian J Publ Health. 40(3):1-18.

[8] Mahatmi H, Setiyono A, Soejoedono RD. 2006. Deteksi Coxiella burnetii penyebab q fever pada sapi, domba dan kambing di bogor dan bali. J. Vet. 28(1):180-187.

[9] Kaplan MM, Bertagna P. 1955. The geographical distribution of q fever. Bull Wld Hlth. 13:829-860.

[10] Nasution SS, Setiyono A, Handharyani E. 2015. Deteksi imunohistokimia antigen Coxiella burnetii sebagai penyebab $q$ fever pada sapi. J. Kedokt. Hew. 9(2): 147-151.

[11] Ogawa M, Setiyono A, Sato K, Cai Y, Shiga S, Kishimoto T. 2004. Evaluation of PCR and nested PCR assays currently used for detection of Coxiella burnetii in japan. Southeast Asian $J$ Trop Med Pub Health. 35(4): 151 -154.

[12] Zhang GQ, Nguyen SAV, To H, Ogawa M, Hotta A, Yamaguchi T, Kim HJ, Fukushi H, Hirai K. 1998. Clinical evaluation of new pcr assay for detection of Coxiella burnetii in human serum samples. J of Clin Micribiol. 36(1):77-80.

[13] [OIE] World Organization of Animal Health. 2015. Q fever worldwide 
https://www.oie.int/wahis 2/public/wahid.php/Diseaseinformatio $\mathrm{n} /$ Diseasedistributionmap/index/newlang/en?disease_type_hidde $\mathrm{n}=0$ \&disease_id_hidden $=22 \&$ selected_disease_name_hidden $=\mathrm{Q}$ + fever+\% $28-+$

$\% 29+\&$ disease_type $=0 \&$ disease_id_terrestrial $=22 \&$ species_t $=0$ \&disease_id_aquatic $=$ -

999\&species_a=0\&sta_method=semesterly\&selected

[14] Anderson A, Bijlmer H, Fournier PE, Graves S, Hartzell J, Kersh

GJ, Limonard G, Marrie TJ, Massung RF, McQuiston JH,
Nicholson WL, Paddock CD, Sexton DJ. 2013. Diagnosis and management of q fever-United States, 2013: recommendations from CDC and the q fever working group. MMWR. 62(3):1-23.

[15] Broke RJ, Kretzchmar MEE, Mutters NT, Teunis PF. 2013. Human dose response relation for airborne exposure to Coxiella burnetii. Infectious Disease. 13:488-495. 